\title{
CCND1/IGLC1 Fusion Gene
}

National Cancer Institute

\section{Source}

National Cancer Institute. CCND1/IGLC1 Fusion Gene. NCI Thesaurus. Code C99369.

A fusion gene that results from a chromosomal translocation $\mathrm{t}(11 ; 22)(\mathrm{q} 13 ; \mathrm{q} 11)$ which places the CCND1 gene on the 5' side of the immunoglobulin light chain locus IGLC1 gene. This rearrang ement may be associated with numerous B-cell malignancies. 